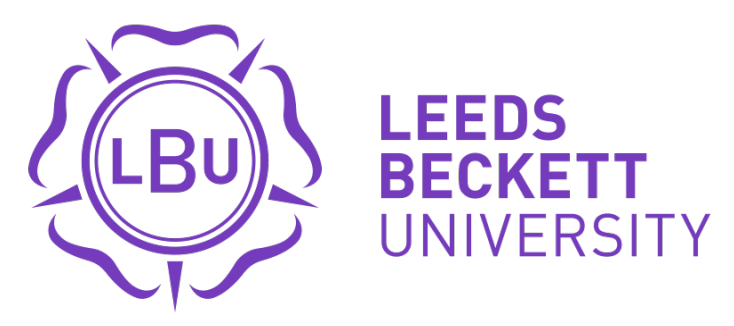

Citation:

Fylan, F and Caveney, L (2017) Young people's motivations to drive: expectations and realities. Transportation Research Part F: Traffic Psychology and Behaviour, 52. pp. 32-39. ISSN 1369-8478 DOI: https://doi.org/10.1016/j.trf.2017.11.011

Link to Leeds Beckett Repository record:

https://eprints.leedsbeckett.ac.uk/id/eprint/4615/

Document Version:

Article (Accepted Version)

Creative Commons: Attribution-Noncommercial-No Derivative Works 4.0

The aim of the Leeds Beckett Repository is to provide open access to our research, as required by funder policies and permitted by publishers and copyright law.

The Leeds Beckett repository holds a wide range of publications, each of which has been checked for copyright and the relevant embargo period has been applied by the Research Services team.

We operate on a standard take-down policy. If you are the author or publisher of an output and you would like it removed from the repository, please contact us and we will investigate on a case-by-case basis.

Each thesis in the repository has been cleared where necessary by the author for third party copyright. If you would like a thesis to be removed from the repository or believe there is an issue with copyright, please contact us on openaccess@leedsbeckett.ac.uk and we will investigate on a case-by-case basis. 


\title{
Young people's motivations to drive: expectations and realities
}

Fiona Fylan ${ }^{\mathrm{a}, \mathrm{b}}$, Lauren Caveneya,

a. Brainbox Research, 46 Town Street, Gildersome, Leeds LS27 7AA

b. Leeds Sustainability Institute, Leeds Beckett University, Leeds LS1 3HE

Corresponding author: Fiona Fylan, Brainbox Research, 46 Town Street, Gildersome, Leeds LS277AA, fiona@brainboxresearch.com

\begin{abstract}
Fewer young adults are choosing to learn to drive and there is a safety argument for encouraging those who do learn to delay doing so. In this study we explore what motivates young people to learn to drive and we uncover their expectations - and the reality - of the difference driving makes to their short- and longer-term futures.

We conducted 12 focus groups with 48 young people age 16-24. The discussions explored why they do or don't want to drive, the immediate life changes that driving brings as well as how driving might affect their life in the future. We analysed the data using thematic analysis using the question: What motivates young people to learn to drive?

We identified five motivations in the data, organised into two themes. The first theme relates to the benefits of maturity. Young people believe driving provides independence and represents the first stage of becoming an adult. Most rely on their parents for lifts, and therefore parents control and scrutinise their social life. The car as a form of personal space was very important for young people, as they have complete control over this environment, which can be missing in other aspects of their lives. Driving also bestows kudos, particularly for those amongst the first in their peer group to pass their test. Novice drivers enjoy being able to offer lifts to friends and family, although described how this rapidly becomes an imposition. The second theme is about broadening horizons. Young people believe that driving expands their social world, enabling them to travel further afield with their friends for day trips because driving is faster, more convenient and cheaper than public transport. In practice, few of those who drive had used their car in this way, instead using it mainly for commuting and getting fast food. Participants talked about how driving opens up career opportunities, allowing them to travel to more distant cities for work and study. However, driving usually made accessing work and study opportunities more convenient rather than possible. Instead, the main benefit young people actually experienced was having more time to sleep in the morning.
\end{abstract}


The qualitative nature of the study, together with the inclusion of pre-drivers, drivers and nondrivers, has provided insight into motivations for learning to drive and how the reality of driving often does not match expectations. The results could be used to inform the potential content of an intervention to encourage young people to delay learning to drive.

\section{Key words}

Young driver, motivation, learning to drive, qualitative

\section{Introduction}

The percentage of young people with a full driving licence decreased in the late 90s in the UK (Le Vine \& Polak, 2014) as well as internationally (Delbosc \& Currie, 2013; Shults \& Williams, 2011; Tefft et al., 2013). In the UK the figure is now approximately steady at $55 \%$ (National Travel Survey, DfT, 2016). The drop in full licence holding in young adults has been attributed to economic reasons (Delbosc \& Currie, 2014; Shults and Williams, 2013). In the UK, young adults are less likely to drive if they have fewer qualifications, lower incomes, live with their parents, live in London or in high density urban areas, live close to public transport, or were born outside of the UK (Le Vine \& Polak, 2014). Cost is the most common deterrent to learning to drive, followed by being able to get lifts from friends and family, and other transport choices being available. Several additional reasons for choosing not to drive have also been proposed, such as the changing social status of the car, greater concern for the environment, and greater reliance on social media than face-to-face communication. Delbosc \& Currie (2014) used an online qualitative approach to explore if and how these attitudes underpinned young Australian adults' decisions around driving. They found that young people saw owning a car as a symbol of maturity rather than social status. There was little evidence that electronic media are replacing face-to-face contact and reducing the need for car travel. Finally, they found young people had few concerns about the impact of driving on the environment and environmental concerns did not impact on their driving decisions.

As well as understanding why young people choose not to learn to drive, it is important to understand why they do, i.e. their motivations for driving and what benefits they anticipate driving will bring them. A quantitative study with young drivers in Australia (Scott Parker, King $\&$ Watson, 2015) found the three reasons for driving are: to gain a sense of freedom; to see friends easily; and to feel independent. Less commonly cited reasons for driving were: to relax; to show you are now an adult; to feel powerful; and to gain status amongst friends. Interestingly, higher scores on driving to show you are now an adult predicts less risky driving. However, while young people have positive beliefs around driving enabling them to spend time with their friends, driving with friends is associated with greater risk-taking behaviour (Christmas, 2008; Moller \& Gregersen, 2008; Moller \& Sigurdardottir, 2009). Young 
people also drive "just for fun" (Laapotti, Keskinen, Hatakka, Hernetkoski, Katilia \& Peraaho, 2006) and for excitement, and the latter predicts traffic offences and injuries on the roads (Blows, Ameratunga, Ivers, Lo \& Norton 2005).

Pre-drivers anticipate that driving will increase their independence, improve their access to further education, widen their employment opportunities, and enable them to contribute to family or household responsibilities (Audrey \& Langford, 2014). The cost of learning to drive and buying and insuring a car was found to be the main deterrent to learning to drive, with lack of time and lack of confidence being less important. However, as the data collection in this research took place after an intervention to encourage young people to delay learning to drive, which included an activity on the cost of driving, the influence of cost might have been elevated. This research included a group of young people from a highly deprived area and so the results may not generalise to other communities, such young people from more affluent areas or those living in more urban or rural settings.

Research to understand decision-making around learning to drive can help inform interventions to encourage young people to delay learning to drive, which is an approach sometimes used by road safety professionals (Audrey \& Langford, 2014) to try to address young people's over-representation in crash statistics in Great Britain (Department for Transport, 2016) and internationally (WHO, 2013). There is potential benefit to young people delaying learning to drive for a few years as people who learn to drive when they are older are less likely to crash (Maycock, Lockwood \& Lester, 1991). While novice drivers generally lack experience of road situations - and therefore the ability to process and anticipate hazards - young drivers can also over-estimate their driving skills, leading to a reduced safety margin (Fuller, 2011). In addition, adolescence is associated with increased impulsivity and sensation seeking (Jonah, 1997; Steinberg, Albert, Cauffman, Banich, Graham \& Wallard, 2008) which can lead to risk taking.

More effective young (pre-) driver interventions can be developed if we understand whether the expected benefits of driving are, in practice, realised. This requires the perspective of both young drivers and pre-drivers. This study explores young people's motivations to learn to drive, with a focus on why they want to drive (or not) and how they imagine their life as a driver will be different in the short term as well as for their long-term future. It identifies and contrasts where pre-drivers' expectations and the realities of being a new young driver diverge.

\section{Materials and methods}

The research took a qualitative approach, based on focus groups with young people in which they explored and discussed their motivations for driving or not driving. Focus groups provide a means of gaining in-depth interviews in a group setting where the dynamics of the group 
lead to young people disclosing thoughts, feelings and experiences that they may not have done so in a one-to-one interview. We developed a focus group topic guide including a series of topics related to driving: why young people want to drive; beliefs about the immediate changes to their lives that driving might bring or has already brought; and beliefs about how driving might affect their future life and opportunities. There were two additional discussion topics to explore the risks young people take on the road and messages that might reduce risk-taking but these results are not reported here. The research was reviewed and approved by the organisational ethics committee. Each focus group lasted around one hour and with permission from participants was audio recorded and transcribed verbatim.

\section{Participants}

A total of 48 young people age between 16 and 24 took part in 12 focus groups. Our sampling strategy was to include participants: who had recently passed their test and who had been driving for several years; who live in urban and in rural areas; who come from different cultural and ethnic environments; who live in economically advantaged and disadvantaged families; who work and who study; who commute by car and who drive primarily for leisure reasons; and who have decided not to drive. To achieve this we used three different participant recruitment methods. We worked with two colleges and ran focus groups with two student groups: one group studying A levels in rural Staffordshire and one group studying BTEC Business in a South Yorkshire town. We worked with one employer in Gateshead to run focus groups with their apprentices. The remainder of the groups were recruited using a professional fieldwork agency. We could therefore specify the ages, areas, employment status and driving status of the participants to ensure there was diversity. Three of these groups took place in West Yorkshire, one in the South East and one in Birmingham. Hence while the groups were not, and were not intended to be, representative of young people in the UK, the young people we included have a range of experiences likely to be relevant to the wider population of young people. The composition of each group is shown in Table 1.

Table 1: Research participants

\begin{tabular}{|c|c|c|c|c|}
\hline Group & Location & Participants & Characteristics & Driving status \\
\hline $1-3$ & $\begin{array}{c}\text { A Sixth Form } \\
\text { College in an } \\
\text { affluent rural area of } \\
\text { the Midlands.. }\end{array}$ & $\begin{array}{c}14 \text { young } \\
\text { people in three } \\
\text { focus groups. } \\
\text { Age } 16-17 .\end{array}$ & $\begin{array}{l}\text { Sixth form students, } \\
\text { many planning on } \\
\text { going to University } \\
\text { later in the year. }\end{array}$ & $\begin{array}{c}0 \text { driving, } 7 \\
\text { learning to drive, } \\
7 \text { planning on } \\
\text { learning to drive. }\end{array}$ \\
\hline $4-5$ & $\begin{array}{l}\text { A Further Education } \\
\text { College based in a } \\
\text { South Yorkshire } \\
\text { town that has both } \\
\text { urban and rural } \\
\text { areas and is an area } \\
\text { of high deprivation. }\end{array}$ & $\begin{array}{c}14 \text { young } \\
\text { people in two } \\
\text { focus groups. } \\
\text { Age } 18-24 \text {. }\end{array}$ & $\begin{array}{c}\text { BTEC Business } \\
\text { students. Included } \\
\text { young people from } \\
\text { different ethnic } \\
\text { minorities and one } \\
\text { participant who uses } \\
\text { a wheelchair and } \\
\text { learnt to drive in an } \\
\text { adapted car. }\end{array}$ & $\begin{array}{c}5 \text { driving, } 4 \\
\text { learning to drive, } \\
1 \text { planning on } \\
\text { learning to drive, } \\
4 \text { not currently } \\
\text { planning to learn. }\end{array}$ \\
\hline
\end{tabular}




\begin{tabular}{|c|c|c|c|c|}
\hline 6-7 & $\begin{array}{l}\text { A City Council in } \\
\text { Gateshead. While } \\
\text { the group took place } \\
\text { in an urban area } \\
\text { some of the young } \\
\text { people lived in rural } \\
\text { areas. } \\
\end{array}$ & $\begin{array}{c}11 \text { young } \\
\text { people in two } \\
\text { focus groups. } \\
\text { Age 18-24. }\end{array}$ & $\begin{array}{l}\text { Apprentices working } \\
\text { in a range of roles, } \\
\text { e.g. plumbing, } \\
\text { business, } \\
\text { administration. }\end{array}$ & $\begin{array}{l}7 \text { driving, } 4 \\
\text { learning to drive. }\end{array}$ \\
\hline 8 & $\begin{array}{l}\text { Leeds, in the North } \\
\text { of England. Urban } \\
\text { area. }\end{array}$ & $\begin{array}{c}4 \text { young people } \\
\text { age } 19-20 \text {. }\end{array}$ & $\begin{array}{c}2 \text { students and } 2 \\
\text { workers. The } \\
\text { students had moved } \\
\text { to Leeds from } \\
\text { Greater London and } \\
\text { the South for their } \\
\text { course. }\end{array}$ & $\begin{array}{l}1 \text { driving, } 2 \\
\text { learning to drive } \\
\text { and } 1 \text { not } \\
\text { currently } \\
\text { planning to learn. }\end{array}$ \\
\hline 9 & Leeds. Urban area. & $\begin{array}{c}4 \text { young people } \\
\text { age } 19-20 .\end{array}$ & $\begin{array}{l}2 \text { students and } 2 \\
\text { workers from Leeds, } \\
\text { Bradford and } \\
\text { Huddersfield. }\end{array}$ & $\begin{array}{l}2 \text { driving, } 1 \\
\text { learning to drive } \\
\text { and } 1 \text { not } \\
\text { currently } \\
\text { planning to learn. }\end{array}$ \\
\hline 10 & $\begin{array}{l}\text { Southend. A town } \\
\text { from which many } \\
\text { people commute to } \\
\text { London. }\end{array}$ & $\begin{array}{c}6 \text { young people } \\
\text { age } 16-19 .\end{array}$ & $\begin{array}{l}2 \text { workers and } 4 \\
\text { students. One high- } \\
\text { school student and } \\
\text { three university } \\
\text { students. }\end{array}$ & $\begin{array}{c}1 \text { driver, } 2 \\
\text { currently } \\
\text { learning, } 2 \\
\text { planning on } \\
\text { starting learning } \\
\text { and } 1 \text { not } \\
\text { currently } \\
\text { planning to learn. }\end{array}$ \\
\hline 11 & Leeds. & $\begin{array}{c}4 \text { young people } \\
\text { age } 18-21 \text {. }\end{array}$ & $\begin{array}{l}3 \text { workers and } 1 \\
\text { student, all from } \\
\text { Leeds and Bradford. }\end{array}$ & $\begin{array}{c}\text { All non-drivers, } \\
\text { none planning on } \\
\text { learning to drive } \\
\text { in the next three } \\
\text { years. }\end{array}$ \\
\hline 12 & $\begin{array}{c}\text { Birmingham, in the } \\
\text { Midlands. } \\
\text { Participants lived in } \\
\text { both urban and rural } \\
\text { areas. }\end{array}$ & $\begin{array}{l}4 \text { young people } \\
\text { age } 19-24 \text {. }\end{array}$ & $\begin{array}{l}1 \text { worker and } 3 \\
\text { students, all from the } \\
\text { West Midlands. }\end{array}$ & $\begin{array}{l}3 \text { drivers, } 2 \text { with } \\
\text { cars and } 1 \\
\text { without. } 1 \text { non- } \\
\text { driver who had } \\
\text { previously taken } \\
\text { lessons. }\end{array}$ \\
\hline
\end{tabular}

\section{Data analysis}

We analysed the data using thematic analysis (Braun \& Clarke, 2006) and the question: What motivates young people to learn to drive? Transcripts were first coded for elements relevant to this question, and then the codes combined with others of similar meaning to create categories. The categories were grouped to form sub-themes that describe the different aspects of motivation. These were then organised into two different themes that represent different types of motivation. One researcher (FF) coded the transcripts and a second (LC) reviewed the themes alongside the codes and original transcripts. Verbatim quotes were selected that best illustrate each sub-theme. 


\section{Results}

We identified five motivations to drive in the data in two different themes, which are described below.

\subsection{Mature benefits}

This theme is about how driving enables young people to enjoy the recognition and rewards arising from their increasing maturity. The three sub-themes are: independence; personal space; and kudos.

\section{Independence}

Participants in all the focus groups talked about how driving is an important first stage of becoming at adult, giving young people freedom and independence. They talked about how being able to drive is a sign of maturity and is usually accompanied by fewer parental restrictions and greater freedoms. Many young drivers described how they had previously relied on their parents for lifts and were therefore forced to organise social arrangements around their parents' availability. Their discussions showed that by parents being the provider of transport, they patrol their children's social life and are aware of where they go, when they go there and who they are with. Young people believed that learning to drive will free them from this scrutiny and mean they do not rely on their parents for their mobility and therefore their social life. The pre-drivers relished the idea of the independence they expect driving will bring and those who already drive all agreed that driving had given them a highly valued independence. Some drivers described how their relationship with their parents had improved, as they no longer needed to ask for lifts. This sense of freedom added to the sense of excitement young people feel about being able to drive.

It's just about being a bit more grown up. It's like the key to adulthood because you've got to be a certain age to do it. So you do feel like you've become more independent at that age. (FG7)

You can go whenever you want to go and not like worry about if my parents are free at that time to pick me up. (FG1)

You can go places with your friends that your parents don't really want to go to. (FG10)

One participant from the non-drivers group challenged the idea that a car is necessary for independence, although she admitted that she relies on her boyfriend for lifts.

Well I feel like l've got freedom and independence without driving because you can still go out and do what you want. Just because I haven't got a car, doesn't mean I can't be independent. Obviously, in a sense it is true because I have to rely on my boyfriend, and stuff, for lifts, but I still think l've got freedom without driving. (FG11) 


\section{Personal space}

Participants talked about a car being their own personal space and how much they value having control over this space. Many of the drivers talked with pride about their car and described how it is the first major purchase they have made. Because they own the car, they decide who to invite into their space and what happens there. This was particularly important for participants still living in the parental home as while they might have had their own bedroom, it is nevertheless in their parents' house, whereas their car belongs entirely to them. In their car they can play music, sing along, and spend enjoyable time with their friends with no need to be careful what they say or not to disturb others. This can lead to them going out in their car just to spend time with friends in their own personal space, rather than to go to a particular destination.

Some people will go out for the night to just sit in a car park in their car with their friends. (FG7)

Participants talked about how travelling in a car is much preferable to travelling on public transport. They can talk without their conversation being overheard by others and they don't need to be concerned about other passengers disapproving of their behaviour. Several explained they don't enjoy getting public transport because of having to sit with strangers. In contrast, young people believed that travelling in their own car is relaxing and enjoyable and if travelling with friends, part of the fun of their trip.

There's music, you can actually talk with your mates. You don't have to worry about things the way you do on the bus, you don't want anybody hearing your conversations, you don't have to try and be quiet. (FG6)

I used to get taken everywhere by my parents and have to ask them if I wanted to go to my friend's. I couldn't play my own music because my Mum hated my music. Then when I'm in my own car I can just basically do whatever I want. (FG8)

\section{Kudos}

The younger participants talked about how driving is something that all their friends want to do, and being among the first to pass your driving test and get a car conveys the respect and admiration of others. Some participants talked about how passing their driving test is the first time they have achieved something recognised: passing the driving test is external validation - they have been judged and found to be worthy. This belief was particularly marked during the focus groups in more deprived areas and with young people who were not, nor planning, to study at university. Some participants described a driving licence as evidence they are capable of learning practical skills. This was particularly important if they did not have many qualifications from school. 
If you've got a car or you're the first person to pass you're one of the cool kids. (FG2)

It is good, it is empowering, it is like the next qualification. (FG4)

A few of the older participants who were taking driving lessons described feeling embarrassed that they have not yet passed their test. This was particularly the case when they had previously failed either theory or practical tests. Many participants discussed how learning to drive is easier when you are younger as it's easier to develop new skills and young people at school or college have more available time to take lessons.

I feel embarrassed that l'm 21 next month and still here, still learning. (FG12)

A few participants talked about how their parents had encouraged them to learn to drive so that they could help out by driving themselves to places and giving other family members lifts. Some drivers talked about how being able to offer family members lifts means they feel more of an adult and equal, rather than one of the children. Novice drivers discussed how it is enjoyable to offer lifts to others and how they like being able to do something helpful and receive gratitude. Those who had been driving for some time talked about how this feeling rapidly wore off, and how being asked for a lift soon starts to feel like an imposition rather than an opportunity.

I was under pressure from my parents because they want to go away in a campervan all over Europe, and they want me to be able to drive so I can give lifts to my sister. (F10)

\subsection{Broadening horizons}

These themes are about how young people believe that being able to drive will mean they have access to more opportunities. There are two sub-themes: expanding social world; and greater career opportunities.

\section{Expanding social world}

Young people believed that driving opens up numerous social opportunities for them. They talked about how driving enables people to go where they want, when they want without having to plan every step of the journey or wait around for buses and trains. Many participants talked about the inconvenience and limitations of public transport that restrict them from visiting places and people or going on trips out. Most participants believed that driving is cheaper than using public transport and so social trips become more affordable and therefore more attractive. However, their discussions indicated they primarily compared the cost of fuel for individual journeys against a public transport ticket. They did not consider the full cost of learning to drive and buying, insuring, maintaining and day-to-day running of a car. Non-drivers discussed how being able to drive would enable them to travel further afield with 
their friends to visit new and more distant places, such as major shopping outlets and nearby big cities. They talked about how driving makes it feasible to have a day or evening out that wouldn't be possible on public transport as it would take too much time.

You might want go to the beach but then you think about how long it will take you to go on the train and like how far the distance from the train to the beach but with a car you can just go to the beach and park near there. (FG5)

Yeah, like if me and my friend arrange to do something, "Ok, I'll pick you up in about five minutes." Then you are all done. If you're not driving you are just constantly having to think "What time have I got to get the bus, when do I have to set off, what time will I arrive there?". It's just more convenient. (FG5)

In practice, few of those who already drive had used their car in this way. Most had used it to go to work or study, to go shopping in nearby supermarkets or shopping centres, to visit friends, and to get fast food.

I use my car to go and buy myself some McDonald's, I can literally just go there. If I couldn't drive, my mum wouldn't take me there. (FG12)

Despite many of the frustrations that young people had of trying to visit friends who might live a short distance away but not on a direct public transport route, few talked about using taxis as an alternative. In contrast, most student participants living in cities believed they could easily manage without a car. They thought that places they wanted to go were close enough to walk and that taxis and public transport were convenient when they needed it.

Being a student, like, you live really close to the centre and stuff anyway, The main city is only like, a five, or ten, minute walk from my house in Newcastle, so I don't really need a car. Like, one of my mates who I live with up in uni, he's got a car and he has to pay for a permit, and stuff like, just to park it on our street. That's like, more money towards what he could use elsewhere if he didn't have a car, but... you just don't need one at uni, like, everything is so close to you. (FG11)

Furthermore, a few participants who were drivers talked about preferring train travel for longdistance journeys as it allows chance to relax or spend the time constructively rather than concentrating on the road.

When I go from London to Leeds I always get the train because it's just more convenient. I don't have to sit and concentrate, I can do my Uni work or I can read a book or something while I'm on the train. I just find it a lot more relaxing, I think, on the train. (FG8) 


\section{Career opportunities}

Nearly all participants talked about how driving opens up more career opportunities, broadens their horizons when exploring career options and makes commuting much more convenient. Participants studying for A levels talked about how being able to drive would mean that they could go to a university further away from home, whilst allowing them to travel back whenever they wanted. However, several participants who were students talked about how a car is not essential for university life and can be an inconvenience. Nobody talked about how access to public transport would enable them to travel further away, despite most universities being well served by public transport.

Young people across the focus groups discussed how being able to drive opens up more job opportunities. They could travel further for work, and therefore work in better jobs. They believed that many jobs require a driving licence, or that career progression is limited for people who cannot drive. A few talked about how their own job would be much more difficult if they could not drive and others said that a car enables them to take advantage of training opportunities, which are often spread around different workplaces. Some of the apprentices were able to use shared cars and vans provided by their workplace and talked about how being able to drive means that they could contribute more to workplace responsibilities and gain more varied experience.

I can't go anywhere in my career really in this industry unless I'm driving because I can't take clients out or I can't drive to inspections. (FG8)

Some participants talked about how it's not feasible to rely on public transport for some jobs, including those with very early or late start or finish times. Most of the employed participants explained that being able to drive means that they can get to work so much faster than by public transport. This reduces the length of their working day, saving them an hour or more on commuting each way to work. Though participants thought they would use the extra time in the morning to get more sleep, they were uncertain how they would use the extra time in the evening.

If you are living in Barnsley and you have got a job in Manchester you don't want to be getting up at silly o'clock in the morning to travel there when it could be a 30 minute ride in a vehicle. (FG4)

There's places that offer work round here that mean leaving at $6.30 \mathrm{am}$ to get the bus, whereas I get to leave 20 minutes before I need to be there now. It's just easier for life. (FG7)

However, one of the working participants in the non-driving group discussed how, having decided not to drive, one of the factors they considered when choosing where to live is the availability of fast, frequent public transport to enable them to easily travel to work. 
Well, I recently moved house because of bus routes and stuff. Where I used to live the buses were shocking and because I don't drive it was an issue. Where I am now the buses are every seven minutes or something stupid like that so it's no issue. It's only ten minutes into town. (FG11)

\section{Discussion}

We have found five different motivations that young people have for learning to drive, grouped into two themes: mature benefits; and broadening horizons. Some of these motivations have been identified previously (Audrey \& Langford, 2014; Scott Parker, King \& Watson, 2015) and the current research provides depth of insight to these motivations, such as the importance of a car as a young person's personal space, the kudos that being amongst the first to drive brings and the embarrassment of being the last, and the importance of a car in expanding young people's social world.

Our first theme - mature benefits - contains three motivators related to feeling and being treated as more mature. Independence is a major motivating factor and young people believe driving means they no longer rely on parents for lifts so that their social life is not scrutinised to the same extent. This potential benefit was realised, and young drivers in our study very much appreciated this aspect of driving. In line with research that shows young people want to show off about their driving (Christmas, 2007, 2008) our younger participants were excited about the prospect of driving and believed that driving confers kudos if you are amongst the first of your peer group to pass your test. However, novice drivers described how the initial excitement of driving rapidly wears off as it becomes a more mundane activity and requests for lifts become an imposition rather than a source of pride. The enjoyment of having one's own personal space did not wear off, however. Young people very much enjoyed being able to control their own environment. This has not been identified in previous research, and it might arise because young people are becoming independent from their parents at a later stage, and leaving home later (Le Vine \& Jones, 2012). While they might have their own bedroom, it is nevertheless in their parent's home, and remains under scrutiny. A car, on the other hand, belongs to them and they can do whatever they want there without asking others' permission. Young drivers very much enjoyed this aspect of car ownership.

Like Audrey and Langford (2014) we found that young people believe a car will expand their study and career opportunities. However, our research shows that though a car may make work and study opportunities more convenient, it rarely makes the difference between being able to take advantage of that opportunity or not. Instead, young people relish the convenience of driving and the prospect of having more time to sleep in the morning. Once young people start driving they find it difficult to imagine returning to long commutes but as pre- and non-drivers these commutes are accepted, if not enjoyed. Young people anticipate 
that their social world will expand once they are freed from the constraints of public transport. By including novice drivers as well as pre-drivers in the research, we were able to show that for many young people living in urban areas these benefits are not realised and public transport serves as well, if not better, than a car. Indeed, people who have good access to public transport are less likely to have a driving licence (Le Vine \& Polak, 2014, Tefft et al., 2014).

Le Vine and Polak (2014) ask why there is a growing number of adults in their 20 s and 30 s who do not hold full driving licences. Our results show that some young people start learning to drive but the cost and the time required means they don't complete the process. By the time they are ready to restart, the motivations for learning to drive that applied in their late teens no longer relevant. For example they may have already become independent from their parents, or their parents no longer patrol their social life, and leaving home has provided them with their own personal space. While freedom from the constraints of public transport was also a motivating factor, some participants who had decided not to drive highlighted that they had made life choices, such as where to live or where to work, based on the availability of public transport.

While the cost of buying, insuring and running a car was a barrier to driving for many of our participants, as has been found elsewhere (Le Vine \& Polak, 2014), they nevertheless believed that a car is more cost effective than public transport. They compared the cost of fuel and parking with that of a public transport ticket and unless prompted, did not take into account the other costs of buying, insuring and maintaining their car. They greatly underestimated typical costs despite very few having parents who contributed to the cost of buying and running their car.

These results have implications for designers of interventions to encourage young people to delay driving. Young people assume that a car will confer independence, personal space, respect from friends, more opportunities to socialise and explore the world, and greater study and career opportunities. In practice, having a car made life more convenient for young drivers, and meant that they could wake up later, but they tended to use their car for more mundane daily tasks, such as shopping and buying fast food. An intervention could therefore help young people to calculate the real cost of driving and compare the value of what they gain for this money (extra sleep and fast food) with alternative potentially more enjoyable and memorable uses - such as socialising or holidays.

We included a large and varied sample in this qualitative research (48 participants from different areas of England) which gives us confidence that the themes we have identified will resonate with young people beyond our sample. However, this study does have several limitations. Though we took care to include participants with a range of different experiences, 
most (7 of 12) of the groups took place in the Midlands or the North of England. Although the groups took place in a variety of towns, cities and rural areas, the findings may be less generalisable to the more affluent young population of the South and London where fewer groups took place. While we included participants from rural areas, these areas nevertheless had public transport. Whereas access to a car is convenient for young people who have a choice between driving and public transport, it is likely to be more of a necessity for young people who live many miles away from public transport routes.

\section{References}

Audrey, S. \& Langford, R. (2014) Dying to get out: young drivers, safety and social inequity. Injury Prevention, 20, 1-6.

Blows, S., Ameratunga, S., Ivers, R.Q., Lo, S.K, \& Norton, R. (2005). Risky driving habits and motor vehicle driver injury. Accident Analysis and Prevention, 37, 619-624.

Braun, V., Clarke, V. (2006). Using thematic analysis in psychology. Qualitative Research in Psychology, 3, 77-101.

Christmas, S. (2007) Road Safety Research Report No. 74. The good, the bad and the talented: Young drivers' perspectives on good driving and learning to drive. London: Department for Transport.

Christmas, S. (2008) Road Safety Research Report No. 86. Feeling Safe, Itching to Drive: Pre-driver and Learner Perspectives on Driving and Learning. London: Department for Transport.

Delbosc, A., Currie, G. (2013) Causes of youth licencing decline: a synthesis of evidence. Transport Review, 33: 271-290.

Delbosc, A., Currie, G. (2014) Using discussion forums to explore attitudes toward cars and licensing among young Australians. Transport Policy, 31: 27-34.

Department for Transport (2016) Reported road casualties in Great Britain: annual report 2015 London: Department for Transport.

Fuller, R. (2011). Driver control theory: From task difficulty homeostasis to risk allostasis, Ch 2. In B. E. Porter (Ed.), Handbook of Traffic Psychology (pp. 13-26). Amsterdam: Elsevier. Jonah, B.A. (1997). Sensation seeking and risky driving: a review and synthesis of the literature. Accident Analysis \& Prevention, 29, 651-665. 
Laapotti, S., Keskinen, E., Hatakka, M., Hernetkoski, K., Katila, A., Peraaho, M., et al (2006). Driving circumstances and accidents among novice drivers. Traffic Injury Prevention, 7(3), 232-237.

Le Vine, S., Jones, P. (2012) On the Move: Making Sense of Car and Train Travel Trends in Britain. London, UK: RAC Foundation.

Le Vine, S., \& Polak, J. (2014). Factors Associated With Young Adults Delaying and Forgoing Driving Licenses: Results From Britain. Traffic Injury Prevention, 15: 794-800.

Maycock, G., Lockwood, C.R. \& Lester, J.F. (1991) The accident liability of car drivers. TRL Report RR315. Crowthorne: Transport and Road Research Laboratory.

Moller, M., \& Gregersen, N. P. (2008). Psychosocial function of driving as a predictor of risktaking behaviour. Accident Analysis and Prevention, 40, 209-215.

Moller, M., \& Sigurdardottir, S. B. (2009). The relationship between leisure time and driving style in two groups of male drivers. Transportation Research Part F, 12, 462-469.

National Travel Survey 2015 (2016) London: Department for Transport.

Scott Parker, B., King, M.J., Watson, B. (2015). The psychosocial purpose of driving and its relationship with the risky driving behaviour of young novice drivers. Transportation Research Part F, 33: 16-26.

Shults, R.A., Williams, A.F. (2013). Trends in driver licencing status and driving among high school seniors in the United States, 1996-2010. Journal of Safety Research, 46,167-170.

Steinberg, L., Albert, D., Cauffman, E., Banich, M., Graham, S., Wollard, J. (2008). Age differences in sensation-seeking and impulsivity as indexed by behaviour and self-report: evidence for a dual systems model. Developmental Psychology ,44, 1764-1778.

Tefft, B.C., Williams, A.F., Grabowski, J.G. (2013). Timing of Driver's License Acquisition and Reasons for Delay Among Young People in the United States, 2012. Washington, DC: AAA Foundation for Road Safety.

World Health Organisation (2013) Global Status Report on Road Safety 2013: Supporting a decade for action. Geneva: World Health Organisation.

\section{Funding}

This research was supported by Brake, the Road Safety Charity. 


\section{Highlights}

- Young people are motivated to drive for: independence; personal space; kudos; expanding their social world; and career and study opportunities.

- While young people gain independence from driving, their car does not expand their social world as much as anticipated and the kudos from driving fades as more of their peers gain their licences.

- Many assume employers expect them to have a driving licence.

- Access to reliable and convenient public transport often removes the desire to drive.

- Once into their 20s, many non-drivers have already achieved many of the benefits driving brings, so they have less desire to learn. 